Prace Literackie LVIII

Wrocław 2018

https://doi.org/10.19195/0079-4767.58.29

\author{
KATARZYNA LISOWSKA \\ ORCID: 0000-0002-2715-0370 \\ Uniwersytet Wrocławski
}

\title{
W jaki sposób metafory wyrażają literaturoznawczy światopogląd? Analiza wybranych tekstów teoretyczno- i krytycznoliterackich
}

W artykule interesować mnie będą specyficzne przejawy metaforyczności występującej w tekstach z obszaru badań literackich. Skupię się na czterech wpływowych w XX i XXI wieku nurtach i na specyficznej, choć bardzo zróżnicowanej grupie wyrażeń. Kwestie te doprecyzowuję w kolejnych akapitach.

W tym kontekście pomocne okaże się przywołanie pojęcia metafory literaturoznawczej, z którą, zdaniem Edwarda Balcerzana, „mamy do czynienia wtedy, gdy jakieś słowo lub wyrażenie, desygnowane pierwotnie do nazywania fenomenów rzeczywistości innej niż literacka, zostaje przeniesione do tekstu badacza (krytyka) literatury i nakierowane na nowe, literackie, fakty czy zdarzenia" . Przyjmuję tę definicję na użytek dalszych rozważań, choć nieco rozszerzam jej zasięg, za przedmiot metaforyzacji uznając nie tylko samą literaturę, lecz także życie literackie. Posługuję się też szerokim rozumieniem przenośni, zgodnie z którym terminem tym można określić każde niekodowane użycie języka ${ }^{2}$, które da się ,sensownie zinterpretować przy uwzględnieniu wszelkiego rodzaju związków motywujących użycie określonego wyrażenia w określonej sytuacji" ${ }^{3}$. Z tego punktu widzenia w obszarze interesującego mnie zabiegu mieszczą się też inne figury i tropy, często od niej odróżniane, takie jak: metonimia, synekdocha, po-

${ }^{1}$ E. Balcerzan. Stowo wstępne (i tu metafora wahadła), [w:] Porwani przez przenośnie. O literaturoznawczych metaforach, red. E. Balcerzan, A. Kwiatkowska, wstęp E. Balcerzan, Poznań 2007, s. 9.

2 T. Dobrzyńska, Metafora, Wrocław 1984, s. 5.

${ }^{3}$ Ibidem. 
równanie, antropomorfizacja i inne ${ }^{4}$. Dlatego też opisane zjawiska można umieścić w szerokim polu metaforyczności, w przyjętym tu rozumieniu obejmującym różnego rodzaju figuratywne użycia języka.

Poza obrębem rozważań pozostawiam przenośnie literaturoznawcze będące, zdaniem Balcerzana, pełnowartościowymi terminami badawczymi ${ }^{5}$ lub ,miniaturowymi, metaforycznymi »teoriami«" zjawisk literackich" ". Interesują mnie bowiem zabiegi pełniące funkcję, którą, luźno nawiązując do rozważań Seweryny Wysłouch ${ }^{7}$, roboczo nazwę metakrytyczną ${ }^{8} \mathrm{i}$ które są głównym przedmiotem moich rozważań. Podstawowym zadaniem tego rodzaju zabiegów jest przywoływanie perspektywy teoretycznej reprezentowanej przez dany tekst ${ }^{9}$. Cytowana badaczka wnikliwie przeanalizowała dwie obszerne grupy metafor literaturoznawczych. Pierwsze z nich to typowe dla kultury europejskiej ${ }^{10}$ literaturoznawcze przenośnie geometryczne, pełniące - dzięki swojej wizualności — funkcję dydaktyczną ${ }^{11}$ i, co szczególnie ważne, będące też wyrazem światopoglądu zakładającego, że wiedzę o literaturze można usystematyzować i przedstawić w kategoriach ogólnych prawidłowości ${ }^{12}$. Druga grupa wyrażeń omówionych przez Wysłouch to metafory gramatyczne ${ }^{13}$ — to właśnie one pełnią, zdaniem badaczki, funkcję paradygmatyczną (zbliżoną do wyróżnionej przez mnie roli metakrytycznej), ukazując podstawowe „założenia strukturalizmu: systemowość i językowy charakter

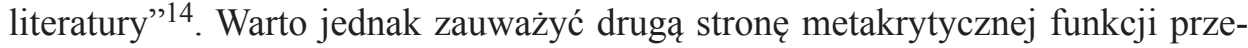
nośni. Otóż podobne zabiegi należące do tych samych pól semantycznych występują niekiedy w tekstach reprezentujących różne ujęcia i mają zdecydowanie inny wydźwięk. Kluczowy zatem okazuje się nie nośnik wyrażenia, lecz to, w jaki sposób zostanie ono użyte i w jakim kontekście umieszczone ${ }^{15}$. Metakrytyczność

${ }^{4}$ Takie szerokie rozumienie metafory przyjmuje na przykład Dorota Korwin-Piotrowska (eadem, Poetyka. Przewodnik po świecie tekstów, Kraków 2011, s. 300-309).

5 E. Balcerzan, Literackość. Modele, gradacje, eksperymenty, Toruń 2013, s. 37.

${ }^{6}$ E. Balcerzan, Stowo wstepne..., s. 10.

${ }^{7}$ Odwołuję się do uwag Seweryny Wysłouch dotyczących paradygmatycznej funkcji przenośni. Proponuję jednak inną nazwę, ponieważ interesujące mnie zabiegi, w przeciwieństwie do wyrażeń opisanych przez badaczkę, opierającą się zresztą na teorii Thomasa S. Kuhna, nie sygnalizują zmiany paradygmatu naukowego (S. Wysłouch, Gramatyka i geometria - dwie miłości (literaturoznawców), [w:] Porwani przez przenośnie..., s. 51). Więcej na temat przedstawianego tu rozumienia metakrytycznego aspektu przenośni pisałam w swojej książce Metaforyczność w dyskursie genderowym polskiego literaturoznawstwa po 1989 roku (Kraków 2019, s. 118-120).

${ }^{8}$ S. Wysłouch, op. cit., s. 51.

${ }^{9}$ Por. ibidem.

10 Ibidem, s. 48.

11 Ibidem, s. 51.

12 Ibidem, s. 46-48, 52.

13 Ibidem, s. 48-51.

14 Ibidem, s. 51.

15 Jak zauważyła bowiem Dorota Kozicka, pisząc o przenośniach wykorzystywanych w krytyce literackiej: „Często te same metaforyczne utarte nazwy [...] będą odsyłały do trochę odmiennych znaczeń, niekiedy będą to nawet różnice zasadnicze" (eadem, Krytyczne (nie)porządki. Studia 
działa zatem dwukierunkowo - z jednej strony metafory współkonstytuują kontekst, z drugiej zaś są przez niego współkonstytuowane (współokreślane).

Dobrym przykładem tego sprzężenia są przenośnie, którym poświęcę dalszą część rozważań. Przyjrzę się mianowicie temu, w jaki sposób metafory mieszczące się w bardzo szeroko rozumianym polu semantycznym cielesności i/lub erotyki przedstawiają perspektywę tekstów pisanych z punktu widzenia czterech odmiennych ujęć badawczych (z naciskiem na ich polskie realizacje, ale bez ograniczania się do nich) - strukturalizmu, poststrukturalizmu (a także związanych z nim dekonstrukcji i dekonstrukcjonizmu), krytyki feministycznej i dyskursu genderowego (nazwę tę odnoszę do kilku odrębnych, ale powiązanych z sobą, nurtów, jak: krytyka genderowa, queerowa, gejowska, lesbijska i studia o męskości). Ze względu na objętość artykułu będę musiała ograniczyć się do szkicowych, bardziej sugerujących niż systematyzujących problematykę uwag. Nie mogąc poddać szczegółowej analizie dużego korpusu tekstów, skupię się zatem raczej na konkretnych przykładach lub, przeciwnie, ogólniejszych tendencjach, które mimo wszystko, mam nadzieję, pozwolą wskazać pewne zależności.

Zazwyczaj tematem interesujących mnie przenośni jest proces twórczy i/lub odbioru (nieco inaczej sytuacja wygląda w dyskursie genderowym). Oczywiście, omówione dalej zabiegi znacząco różnią się pod względem formalnym. Co więcej, niekiedy cielesność i erotyka nie są ich, można powiedzieć, macierzystymi polami semantycznymi - czasem wyrażenia te znajdują się bowiem w obrębie analizowanej leksyki niejako wtórnie, ,przybywszy” z innego kontekstu. Istotne jest jednak, że wszystkie przedstawione dalej zabiegi w jakiś sposób, bardziej lub mniej wyraźny, nawiązują do problematyki cielesności i/lub erotyki.

Należy też zaznaczyć, że obecność wspomnianej metaforyki w badaniach poststrukturalistycznych i feministycznych jest zjawiskiem od dawna rozpoznanym i szeroko opisanym. Celem moich rozważań jest zatem nie odkrycie nowych cech tych perspektyw, lecz przyjrzenie się im z punktu widzenia tego, jak omawiane przenośnie obrazują podstawowe założenia danych nurtów, a także zastanowienie się, na czym polega specyfika analizowanych tropów. Porównanie różnych ujęć pod kątem podobnej, a jednocześnie odmiennej metaforyczności pozwoli, mam nadzieję, dołączyć małą cegiełkę do gmachu rozważań teoretycznych (to oczywiście także przenośnia) na temat kilku wpływowych w ostatnich dziesięcioleciach ujęć.

Uwagi dotyczące poststrukturalizmu (i bliskich mu, choć oczywiście nietożsamych z nim, dekonstrukcji i dekonstrukcjonizmu) ograniczę do wskazania kilku kluczowych wątków będących podstawowym kontekstem różnych zastosowań interesujących mnie wyrażeń ${ }^{16}$. Nie analizuję zatem szczegółowo tekstów

o wspótczesnej krytyce literackiej w Polsce, Kraków 2012, s. 45; por. też K. Lisowska, Metaforyczność $w$ dyskursie genderowym..., s. 119, przyp. 73).

${ }^{16}$ Swoje obserwacje opieram przede wszystkim na spostrzeżeniach przedstawionych przez Annę Burzyńską w książce Anty-teoria literatury (Kraków 2006), a konkretnie w rozdziale pod znamiennym tytułem Literatura, komunikacja i mitość (s. 149-174). 
literaturoznawczych mieszczących się w obrębie tego nurtu, lecz eksponuję pewne teoretyczne, a w konsekwencji także stylistyczne założenia (i na odwrót?) tej perspektywy, które stały się ramą wypowiedzi w różny sposób nawiązujących do przełomu poststrukturalistycznego. Jednym z głównych kontekstów metaforyki cielesności i erotyki są bowiem, jak się zdaje, między innymi rozważania Jacques'a Derridy, Michela Foucaulta i, zwłaszcza, Rolanda Barthes'a ${ }^{17}$. Jak można wywnioskować $\mathrm{z}$ analiz Anny Burzyńskiej ${ }^{18}$, to właśnie refleksja ostatniego z wymienionych teoretyków jest szczególnie istotnym punktem odniesienia interesujących mnie wyrażeń. Za Burzyńską warto wskazać, że trzej wymienieni filozofowie upominali się o „uczucia”, „cielesność” i „namiętności” podmiotów uczestniczących w komunikacji literackiej, czyli o wartości nieobecne w strukturalnej semiotyce, której założenia podważali ${ }^{19}$. Barthes, wskazując cielesny i zmysłowy aspekt lektury ${ }^{20}$, dążył do przeformułowania (a raczej obalenia) modelu komunikacji literackiej ${ }^{21}$ obowiązującego w strukturalizmie, semiotyce ${ }^{22}$ czy — w polskim kontekście — w ,szkole komunikacyjnej”23. Nie bez powodu, jak słusznie zauważa Burzyńska, ,jedna z najbardziej [...] namiętnych krytyk teorii komunikacji" ${ }^{24}$ została wypowiedziana we Fragmentach dyskursu mitosnego Barthes'a ${ }^{25}$.

17 A. Burzyńska, Anty-teoria literatury..., s. 157-164, 171-174. Na temat roli ciała w tekstach Barthes'a i Derridy zob. też M. Karasińska, Na scenie tekstu, [w:] Porwani przez przenośnie..., s. 33. Oczywiście ta lista nazwisk nie wyczerpuje autorów i autorek związanych z poststrukturalizmem i dekonstrukcją i nawiązujących w swoich teoriach do cielesności. Warto między innymi wspomnieć o Julii Kristevej i jej koncepcji polilogicznego - cielesnego właśnie — podmiotu (por. J. Kristeva, Polylogue, Paris 1977, uwagi na temat publikacji za: E. Rewers, Język i przestrzeń w poststrukturalistycznej filozofii kultury, Poznań 1996, s. 163-164, 167). Prace tej badaczki nawiązują zresztą nie tylko do wskazanych perspektyw, lecz także są jednym z ważniejszych obszarów przedstawionej dalej myśli feministycznej.

${ }^{18}$ A. Burzyńska, Anty-teoria literatury..., s. 171-174. Por. też uwagi Michała Pawła Markowskiego dotyczące problemu cielesności w koncepcjach Barthes'a (M.P. Markowski, Ciało, które czyta, ciało, które pisze, [w:] R. Barthes, S/Z, przeł. M.P. Markowski, M. Gołębiewska, Kraków 1999, s. 28, 30-31).

${ }^{19}$ A. Burzyńska, Anty-teoria literatury..., s. 163.

${ }^{20}$ Ibidem, s. 171. Burzyńska powołuje się na odczytanie Barthes'a zaproponowane przez Wincentego Grajewskiego (por. W. Grajewski, Nauka lektury wedtug Rolanda Barthes' $a$, [w:] Problemy odbioru i odbiorcy. Studia, red. T. Bujnicki, J. Sławiński, Wrocław 1977).

${ }^{21}$ A. Burzyńska, Anty-teoria literatury..., s. 171-173.

${ }^{22}$ Trzeba przy tym przypomnieć, że w myśli samego Barthes'a relacje między strukturalizmem i semiotyką a poststrukturalizmem są bardzo skomplikowane i niejednoznaczne (por. choćby D. Eribon, Michel Foucault et ses contemporaines, Paris 1994, s. 211-232; oraz M.P. Markowski, op. cit., s. 9-19).

23 A. Burzyńska, Anty-teoria literatury..., s. 152.

${ }^{24}$ Ibidem, s. 173. Jeśli nie zaznaczono inaczej, wyróżnienia są moje — K.L.

${ }^{25}$ Ibidem (autorka powołuje się na: R. Barthes, Fragmenty dyskursu miłosnego, przeł. M. Bieńczyk, Warszawa 1999). Na marginesie warto dodać, że pozostając w obrębie miłosnej stylistyki, w zakończeniu omawianego rozdziału Burzyńska zauważa: „być może wytarte już dzisiaj powiedzenie »kocham literaturę« nabierze świeżego znaczenia” (eadem, Anty-teoria literatury..., s. 174). 
Wydaje się zatem, że Barthes, Foucault i Derrida, dowartościowując cielesność i zmysłowość czytelniczego doświadczenia, stworzyli jednocześnie punkt odniesienia otwartego zbioru metafor istniejących w tekstach w różny sposób nawiązujących do rozpoznań poststrukturalizmu czy też czerpiących z pewnych (dość obiegowych) koncepcji kojarzonych z tym nurtem (chodziłoby zatem przede wszystkim o nacisk na przyjemność i korporalność lektury oraz rolę doświadczenia autobiograficznego, a także przeformułowanie zależności między autorem/autorką a tekstem ${ }^{26}$, ale nie, jak pokazują choćby przykłady krytycznofeministyczne, jej całkowite zlikwidowanie). Osobną, niemożliwą do rozwikłania w tym miejscu kwestią pozostaje jednak pytanie o to, w jakim stopniu poststrukturalistom i idącym w ich ślady dekonstrukcjonistom udało się uchwycić rzeczywistą (?) cielesność dyskursu, a w jakim poddali także i ten aspekt tekstualizacji. Zdaniem Moniki Świerkosz wspomniani teoretycy „w swoich lekturach wybrali [bowiem - dop. K.L.] przyglądanie się tkaninie zamiast słuchania [zmieniam końcówkę fleksyjną - K.L.] historii tkaczki" ${ }^{27}$. Z perspektywy moich rozważań istotne są zatem dwie kwestie: nie tylko dowartościowanie metaforyki cielesności i erotyki, lecz także podkreślenie paradoksów wynikających z tego zwrotu. Do aporii interesującej mnie metaforyczności będę jeszcze powracać.

Popularność metaforyki ${ }^{28}$ cielesności i erotyki w krytyce feministycznej, zwłaszcza w drugiej fali, w której zabiegi te rozwinęły się w, jak pisze Monika Świerkosz, „hipermetaforę”29, przynajmniej częściowo wynikała z afirmacji

26 Trzeba także zwrócić uwagę, że Foucault niejednokrotnie podkreślał autobiograficzne, a zatem jak sądzę także materialno-cielesne podłoże swojej teorii, zaprzeczające zresztą uproszczonym interpretacjom jego koncepcji autora (por. D. Eribon, op. cit., s. 51, 60-62, 67).

${ }^{27}$ M. Świerkosz, Arachne i Atena. Literatura, polityka i kobiecy klasycyzm, Kraków 2017, s. 22; autorka pisze o odczytaniach Barthes'a, Josepha Hillisa Millera i Geoffreya Hartmana (ibidem; por. też ibidem, przyp. 31).

${ }^{28}$ Można także argumentować, że z perspektywy feministycznej ważniejszym zabiegiem jest metonimia. Trop ten, kojarzony z chaosem i przyległością, bywał bowiem przeciwstawiany przenośni, mającej się cechować hierarchią i logocentryzmem (zob. P. Dybel, Zagadka ,drugiej ptci”. Spory wokól różnicy seksualnej w psychoanalizie $i$ w feminizmie, Kraków 2012, s. 433, 435-436, 462-463, 475-479; L. Edelman, Homographesis. Essays in Gay Literary and Cultural Theory, London-New York 1994, s. 8-9, 13, 14-15, 88, 90, 245). Jednak z punktu widzenia przyjętego przeze mnie szerokiego ujęcia metafory/metaforyczności granice (także ideologiczne) między oboma pojęciami wydają się zacierać i dlatego również w części rozważań poświęconej dyskursowi feministycznemu zajmuję się właśnie przenośnią (jak zresztą słusznie zauważa Paweł Dybel: „obie figury [...] nie są w stosunku do siebie rozłączne, ale funkcjonują na zasadzie wzajemnej implikacji. Nie ma takiej metonimii, która, jako operacja »dodania« znaczących, nie zawierałaby w sobie operacji ich substytucji. I na odwrót. [...] Różnica między tymi dwoma figurami wynika przede wszystkim stąd, że w każdej z nich jedna ze wspomnianych operacji pełni rolę dominującą, podczas gdy druga gra rolę swoiście wspomagającego ją tła" (P. Dybel, op. cit., s. 434-435; por. też K. Lisowska, Metaforyczność $w$ dyskursie genderowym..., s. 133-137; relacje między oboma zabiegami są zresztą osobną, szeroką omówioną kwestią, której nie sposób w pełni przedstawić w niniejszym artykule).

${ }^{29}$ M. Świerkosz, Poza metaforę? Od feminizmu korporalnego do korporalnej teorii narracji, [w:] Anatomia dyskursu. Wiedza o literaturze z punktu widzenia obserwatora III, red. B. Balicki, B. Ryż, E. Szczerbuk, Wrocław 2008. Przenośnie te opisywały proces twórczy (ibidem, s. 181). 
kobiecej odmienności, wiązanej niekiedy właśnie z korporalnością ${ }^{30}$. Dowartościowanie tej sfery, kojarzonej zresztą w kulturze zachodniej z domeną kobiet, pozwalało zaproponować odmienny od rzekomo uniwersalnego, a z perspektywy feministycznej (i, jak wspomniałam, szerzej, z punktu widzenia ujęć zainspirowanych poststrukturalizmem i dekonstrukcją) logocentrycznego i patriarchalnego, model pisarstwa i autorstwa. Nie bez powodu zatem kategoria kobiety autorki i ściśle z nią związane pytanie o odmienność kobiecego stylu należały do sfer, w których interesujący mnie typ metaforyczności odegrał szczególną rolę, co zauważymy choćby w takich koncepcjach jak arachnologia Nancy K. Miller czy francuskie écriture féminine ${ }^{31}$. Na polskim gruncie jako przykład można podać dobrze znaną metaforę drożdży Grażyny Borkowskiej ${ }^{32}$. Stworzona przez badaczkę przenośnia miała przecież eksponować cielesność i, można powiedzieć, nieskrępowaną seksualność kobiecego pisarstwa, czego dowodzą choćby trzy cytaty:

Przyjmijmy, że o literaturze/poezji kobiecej możemy mówić wtedy, kiedy podmiot utworu odsłoni swą płciowość, dokona seksualnej samoidentyfikacji ${ }^{33}$.

Wydaje się, że wszędzie tam, gdzie możemy mówić o literaturze/poezji kobiecej, a więc tam, gdzie dochodzi do odsłonięcia kategorii płci, przyczyną i siłą sprawczą jest presja seksualności, nieforemnej, rozlanej jak pączkujące drożdże ${ }^{34}$.

wszędzie tam, gdzie akcentuje się płciowość podmiotu mówiącego, wszędzie tam, gdzie ujawnia się związek między ciałem a tekstem — mamy do czynienia z przypadkiem literatury/poezji kobiecej $^{35}$.

Choć wspomniana metafora jest bezpośrednio obecna tylko w drugim z cytatów, to wszystkie fragmenty nawiązują do projektu literatury opisanej przez ten trop. Drożdże to zatem nośnik wyraźnie odwołujący się do cielesnego i erotycznego wymiaru kobiecego pisarstwa, akcentowanego przez Borkowską zarówno eksplicytnie, jak i figuratywnie.

${ }^{30}$ Ibidem, s. 180.

${ }^{31}$ Por. A. Burzyńska, Feminizm, [w:] A. Burzyńska, M.P. Markowski, Teorie literatury XX wieku. Podręcznik, Kraków 2007, s. 409-416; M. Świerkosz, Poza metaforę..., s. 199. Co ważne, jak wskazuje Świerkosz, w drugiej ze wspomnianych koncepcji szczególną rolę odgrywały właśnie metafory, mające wskazywać na związek cielesności, seksualności i literatury.

32 G. Borkowska, Metafora drożdży. Co to jest literatura/poezja kobieca, [w:] Ciało i tekst. Feminizm w literaturoznawstwie — antologia szkiców, red. A. Nasiłowska, Warszawa 2001, s. 65-76.

33 Ibidem, s. 71.

${ }^{34}$ Ibidem, s. 76.

35 Ibidem. Trzeba dodać, że dla Borkowskiej nie ma znaczenia faktyczna płeć biologiczna autora/autorki (zob. ibidem, s. 70-71, 76). Kobiece pisanie jest zatem specyficznym stylem, dostępnym dla różnych podmiotów. Wątek ten często się pojawia w różnych ujęciach literatury kobiecej, między innymi w obrębie écriture féminine, w której to koncepcji podkreśla się biseksualność piszącej osoby mogącej przyjąć pozycję kobiecą lub męską (por. A. Araszkiewicz, Zapomniana rewolucja. Rozkwit kobiecego pisania w dwudziestoleciu międzywojennym, Warszawa 2014, s. 54-55; zob. też przytoczone przez Araszkiewicz rozważania Krystyny Kłosińskiej, Feministyczna krytyka literacka, Katowice 2010, s. 417). 
Co ważne, w polskiej krytyce feministycznej znajdziemy również przykłady przenośni z pola semantycznego cielesności obrazujące niejako drugą stronę przedstawionego zjawiska, czyli nie relację między autorką a jej tekstem, lecz związek między interpretatorką a czytanym utworem. W tym kontekście warto wskazać kilka przykładów zaczerpniętych z prac Ingi Iwasiów ${ }^{36}$, która posługuje się metaforami uwodzenia i pieszczoty, a także miłosnego spotkania z tekstem:

Wszystkie te feministyczne historie założycielskie można by zinterpretować, potraktować jako schematy fabularne. Co wówczas oznacza moja fabuła? Myślę, że ciągłą grę uwiedzeń, zwo dzeń i oporu. Grę, w którą gram z patriarchatem. Nie mogę go unieważnić, więc się z nim trochę pieszczę, żeby odnosić, przy bliższym poznaniu, swoje zwycięstwa. [...] metafora pieszczoty, stosowana tutaj, ma oznaczać coś innego niż „kobiecy sposób” na zyskanie uznania. To metafora, przy pomocy której chcę wyrazić swoje emocje i swój namysł. Pieszczę się z męskim tekstem kultury na swoich prawach, nie odrzucam go, ale świadomie wykorzystuję 37 .

Czytanie Lalki to przypadek czystej miłości. Wiem, że nie powiem niczego nowego. Że spierać się mogę z całym światem, który pseudonimuje; ze światem odtwarzanym przez poprzedników. Nie wygram. Nie zrobię niczego, co byłoby czymkolwiek poza miłosnym spotkaniem z tekstem ${ }^{38}$.

W tych cytatach proces odbioru jest przedstawiony jako relacja erotyczna, zakorzeniona w cielesności i namiętności czytającej podmiotki, co przywodzi na myśl powołaną wcześniej za Burzyńską koncepcję Barthes’a. Co ciekawe, o ile w pierwszym z przytoczonych fragmentów odbiorczyni wydaje się na swój sposób niezależna (odnoszenie zwycięstw, świadome wykorzystywanie utworu; por.

${ }^{36}$ Wspominam o Indze Iwasiów w kontekście krytyki feministycznej, ponieważ ta perspektywa jest bardzo wyraźnie obecna w jej pracach. Zdaję sobie jednak sprawę, że umieszczenie autorki wyłącznie w obrębie tego nurtu byłoby uproszczeniem, ponieważ, jak słusznie zauważyła Ewa Kraskowska, w badaniach Iwasiów „w zasadzie nie ma [...] różnicy między krytyką feministyczną a genderową" (eadem, Dyskurs feministyczny w stowiańskiej literaturze, krytyce i teorii po roku 1989, [w:] Literatury stowiańskie po 1989 roku. Nowe zjawiska, tendencje, perspektywy, t. 2. Feminizm, red. E. Kraskowska, Warszawa 2005, s. 14). Dlatego też powołuję się na badaczkę także w dalszej części rozważań, poświęconej drugiej z wymienionych perspektyw badawczych.

37 I. Iwasiów, Rewindykacje. Kobieta czytająca dzisiaj, Kraków 2002, s. 15-16. Na marginesie warto wskazać na dwie kwestie. Po pierwsze, na autotematyczny czy też metateoretyczny charakter przytoczonego cytatu, w którym autorka celowo podkreśla metaforyczny wymiar zastosowanych przez siebie wyrażeń. Po drugie, pojawiają się tu określenia dotyczące uwodzenia, oporu i wykorzystywania, odsyłające nas do zabiegów przedstawionych w kolejnych, poświęconych strukturalizmowi, akapitach. Kwestię tę rozwijam dalej.

${ }^{38}$ I. Iwasiów, Parafrazy i reintepretacje. Wyktady z teorii i praktyki czytania, Szczecin 2004, s. 66. Por. też tytuł pierwszej części cytowanej publikacji: Od erotyki literatury do paru pytań o uwiedzenia i zawody metodologiczne (s. 13-54). Warto też zwrócić uwagę na metafory uścisku („Oba te pojęcia [»antyinterpretacja« i »nie-interpretacja« — dop. K.L.] pozostają w uścisku, by nie użyć słowa »klincz« — wolę uścisk, kojarzący się z czułością i osobistą relacją", ibidem, s. 9) i uwiedzenia („Uwiedzenie [tekstu/przez tekst; jest lepsze — dop. K.L.] — od rozbiórki”, ibidem, s. 10) pojawiające się we Wstępie do wspomnianej książki. 
też przyp. 37), o tyle w drugim okazuje się ona bezradna wobec obezwładniającej sily tekstu.

Jak widzimy, metaforyka cielesności pełni funkcję metakrytyczną: opisuje nie tylko domniemaną ${ }^{39}$ specyfikę literatury kobiecej, relację między autorką i/lub interpretatorką a tekstem, lecz także rewaloryzuje cielesność jako sferę wykluczoną z głównego nurtu kulturowego dyskursu, ufundowanego przez logocentryzm i podkreślanie rozdźwięku między podmiotem a przedmiotem ${ }^{40}$. Ostatnia kwestia jest szczególnie ciekawa, a zarazem skomplikowana, ponieważ wiąże się ze wspomnianym już wcześniej paradoksalnym wymiarem cielesności metafor. Cytowana w kontekście poststrukturalizmu Świerkosz wskazuje na niejasny status korporalności także w obrębie dyskursu feministycznego, zwłaszcza w écriture féminine. Jak zauważa badaczka, istotnym zarzutem wobec tej koncepcji

był zarzut metaforyzacji kulturowego doświadczenia ciała i sposoby mówienia o nim. Cixous, choć w swych żarliwych manifestach nawoływała do koncentracji na ekspresji ciała jako źródle kobiecej twórczości, ostatecznie jednak myślała o ciele jako o pewnej figurze. Przeświadczenie o bezpośredniej i dosłownej tożsamości ciała kobiecego z tekstem, [sic!] możliwe było do utrzymania o ile materialny porządek ciała został wtłoczony w dyskursywny porządek tekstu ${ }^{41}$.

W konsekwencji, jak dodaje autorka, cielesność nierzadko poddawano niepotrzebnej metaforyzacji, „która często była i jest sposobem na zepchnięcie ciała wyłącznie do roli pretekstu"42. Tendencja do mówienia o cielesności (kobiecego) tekstu — zauważa badaczka — przerodziła się zatem w metaforyzowanie (,,»tekst jak ciało«") ${ }^{43}$, przysłaniające pytanie o to, jak właściwie „w lekturze dostrzec [...] związek materialnego i cielesnego" 44 .

Tak jak wspomniałam, popularność metaforyki cielesności i erotyki w pracach poststrukturalistycznych i feministycznych jest dzisiaj niemal oczywistością (żeby nie powiedzieć — banałem). Równie jasna (naturalna?) mogłaby się wy-

${ }^{39}$ Nie rozstrzygam, czy na tym w istocie opiera się specyfika literatury kobiecej (ani, bo do tego podstawowego pytania też należałoby sięgnąć, czy zasadne jest jej wyodrębnianie). Z ograniczaniem tego typu pisarstwa do twórczości w różny sposób akcentującej cielesność tekstu w swojej najnowszej pracy dyskutuje Monika Świerkosz (por. eadem, Arachne i Atena ..., tu s. 29-30; trzeba przy tym zaznaczyć, że cel badaczki stanowi nie odrzucenie „somatycznego" ujęcia kobiecej literatury, lecz wskazanie typów pisarstwa w inny sposób ujmujących problematykę korporalności i racjonalności - por. ibidem, s. 48-49).

${ }^{40}$ Por. uwagi Burzyńskiej na temat koncepcji Nancy K. Miller (A. Burzyńska, Feminizm ..., s. 401, 409-411). Należy także wspomnieć o komentarzu Świerkosz, w którym autorka komplikuje najbardziej rozpowszechnione interpretacje tego ujęcia (eadem, Arachne i Atena ..., s. 20-23), wskazując na złożony i polemiczny status cielesności (i jej (nie)metaforycznego aspektu) w propozycji amerykańskiej badaczki (por. „wbrew teoretyczkom écriture féminine nie interesuje jej mniej lub bardziej metaforycznie rozumiana »cielesność kobiecego tekstu«, lecz ucieleśniona w tekście i rozumiana nadal personalistycznie osobowość autorska" (ibidem, s. 22).

${ }^{41}$ M. Świerkosz, Poza metaforę..., s. 181.

42 Ibidem, s. 201.

${ }^{43}$ M. Świerkosz, Arachne i Atena ..., s. 18, przyp. 21.

${ }^{44}$ Ibidem, por. też M. Świerkosz, Poza metaforę... 
dawać jej nikła obecność w badaniach strukturalistycznych, których umiłowanie abstrakcyjnych systemów sytuuje się na antypodach perspektyw uprzywilejowujących wartości takie jak namiętność, zmysłowość i cielesność lektury. Rzeczywiście, we wspomnianym nurcie trudno się doszukać licznych przywołań interesujących mnie zabiegów, jednak nie oznacza to, że nie ma ich wcale. Trzeba przy tym zaznaczyć, iż będzie tu mowa o specyficznej modyfikacji strukturalizmu, jakim jest polska szkoła komunikacji literackiej, a konkretnie teksty jednego z jej najwybitniejszych przedstawicieli, czyli Janusza Sławińskiego.

Wspomniany autor nawiązuje do omawianych przenośni w dość luźny, ale znamienny sposób. Jak wiadomo, metafory stosowane przez badacza wnikliwie i błyskotliwie przeanalizował Erazm Kuźma ${ }^{45}$ i nie ma sensu w całości referować jego spostrzeżeń. Co jednak ważne, w analizie badacza — z pewnością nie bez powodu - nie pojawiają się wyrażenia z pola erotyki i cielesności. Z kolei duże znaczenie autor przywiązuje do wyrażeń wykorzystujących leksykę militarną ${ }^{46}$ i do nadbudowującej się nad nimi metafory rezerwatu, uznanej przez Kuźmę za podstawową dla tekstów Sławińskiego ${ }^{47}$. I to właśnie w tym kontekście w wypowiedziach autora Koncepcji języka poetyckiego Awangardy Krakowskiej pojawiają się niekiedy, niejako chyłkiem, wyrażenia nawiązujące do zabiegów będących głównym przedmiotem moich rozważań. Jak jednak nietrudno się domyślić, ze względu na zarysowane „okoliczności” stylistyczne cielesność i erotyka funkcjonują w tych wyrażeniach w zupełnie inny sposób niż w przedstawionych wcześniej pracach poststrukturalistycznych i feministycznych. Występują one bowiem w ramie przymusu, przemocy ${ }^{48}$, a w konsekwencji także gwałtu. Pisząc o jednej z wyróżnionych przez siebie faz interpretacji tekstu literackiego, Sławiński konstruuje następujący obraz:

swoją strategię rozpoznaje [ona - K.L.] dopiero w działaniu, bezpośrednim kontakcie z utworem: wtedy naprawdę dowiaduje się, czym być powinna. Sytuacja tak wygląda niezależnie od tego, jak wyobrażamy sobie ów kontakt: czy ujmujemy go w kategoriach uległości wobec dzieła, uznania jego autonomii i uszanowania zamkniętej w nim „tajemnicy”, czy — przeciwnie — w kategoriach napastliwości, przymusu i gwałtu, do których ucieka się interpretator, usiłując zawładnąć tajemnym sensem dzieła ${ }^{49}$.

Konotacje zacytowanych przykładów można by naturalnie zredukować do kontekstu wojennego (,gwałt”, „przymus”, „opanowywanie” to przecież określe-

45 E. Kuźma, Metafory Janusza Stawińskiego, „Teksty Drugie” 1994, nr 4, s. 27-36.

${ }^{46}$ Kuźma mówi w tym kontekście o metaforach odwołujących się „do relacji czasowych”, metafor „działania”, „akcji”, do których należą przenośnie nawiązujące do „gier wojennych i gier społecznych" (ibidem, s. 30).

${ }^{47}$ Ibidem, s. 31-36.

48 Dlatego też — o czym nie można zapominać — macierzystym i, jak sądzę, zamierzonym, kontekstem stylistycznym tego rodzaju zabiegów jest oczywiście leksyka militarna. Jednak z perspektywy moich rozważań istotne wydaje się zwrócenie uwagi także na ich dodatkowe konotacje.

49 J. Sławiński, Analiza, interpretacja i wartościowanie dzieła literackiego, [w:] idem, Próby teoretycznoliterackie, Kraków 2000, s. 31. 
nia opisujące zmagania na polu walki), trudno jednak nie dostrzec ich wieloznaczności, zwłaszcza w zestawieniu z wyraźniej odnoszącymi się do sfery seksualności i erotyki określeniami takimi jak „napastliwość” i „uległość”, nie mówiąc już o tym, że (seksualny) gwałt jest przecież — niestety — stałym elementem działań militarnych. Mimo iż trzeba odróżnić przenośnie wykorzystane w drugiej części cytatu, które obrazują działania interpretatora nakierowane na podporządkowanie sobie utworu, od pojawiającej się wcześniej metafory uległości, przedstawiającej przeciwną postawę, to oba typy zabiegów odwołują się do gwałtu.

Warto przywołać jeszcze kilka podobnych, choć znacznie subtelniejszych zabiegów autorstwa Sławińskiego. Wyrażenia te tematyzują różne kwestie. Mowa na przykład o „uległym podawaniu się konieczności” ${ }^{50}$, czyli postępowaniu charakterystycznym dla jednej z wyróżnionych przez autora strategii analitycznych ${ }^{51}$. Jak widzimy, w tym wypadku to badacz okazuje się stroną podporządkowaną utworowi. Z kolei omawiając niedostatki pewnego typu ,języków interpretacyjnych"52, Sławiński wskazuje, że ujęcia te, korzystające z narzędzi analitycznych wypracowanych $\mathrm{w}$ innych nurtach, nie są $\mathrm{w}$ stanie ,detalicznie opanować utworu, zawładnąć nim, uczynić go bezspornie własnym [wyr. oryg. - K.L.] obiektem"53. Po raz kolejny zatem mamy do czynienia z wyrażeniami zakorzenionym w metaforyce militarnej, ale zarazem delikatnie (o ile to słowo jest w tym kontekście stosowne) nawiązującymi do pola semantycznego gwałtu, na co wskazuje przede wszystkim dążenie (co prawda nieudane) do uprzedmiotowienia, podporządkowania sobie obiektu badań. W tym fragmencie, podobnie jak w przykładzie przytoczonym wcześniej, mowa o badaczu ponoszącym porażkę i przegrywającym — by posłużyć metaforyką wojenną — starcie z tekstem. Podobna stylistyka i semantyka pojawiają się również w opisie działań interpretatora zmierzającego do tego, by ,uczynić z wypowiedzi cudzej obiekt swojej, uprzedmiotowić [wyr. oryg. - K.L.] tę cudzą, własnej zaś przyznać zdolność do poznawczego panowania nad tamtą"54; co jednak ważne, Sławiński podkreśla, że pełne zrealizowanie tego założenia jest w zasadzie niemożli$\mathrm{we}^{55}$, ironicznie - a zarazem za pomocą interesującej mnie metaforyki — przedstawiając strategie interpretacyjne uznane za jednostronne ${ }^{56}$ :

Interpretacje mają mianowicie zawładnąć obiektami indywidualnymi znajdującymi się w domenie przedmiotowej literaturoznawstwa (w naszym wypadku — utworami), a więc przymu-

${ }^{50}$ Ibidem, s. 19 (parafrazuję: ,ulegle poddaje się konieczności”).

51 Ibidem. Chodzi o, mówiąc językiem Sławińskiego, „taktykę”, która godzi się na „zerwanie ciągłości” badania, akcentując „dwujęzyczność” analizy, odzwierciedlającą dwupłaszczyznowość dzieła złożonego z „planu wyrażania” i ,planu treści” (ibidem).

52 Ibidem, s. 25.

53 Ibidem.

54 J. Sławiński, Uwagi o interpretacji (literaturoznawczej), [w:] idem, Próby teoretycznoliterackie..., s. 42.

55 Ibidem.

56 Ibidem, s. 43. 
sić je do tego, by stały się zrozumiałe (by odkryły swój sens) w świetle pojęć danej teorii. Narzędziem przymusu jest schemat opisu i wyjaśniania $\mathrm{z}$ teorii takiej wywiedziony ${ }^{57}$.

Wszystkie przytoczone w poprzednich dwóch akapitach wyrażenia, luźno nawiązujące do pola semantycznego gwałtu, pełnią zarazem funkcję metakrytyczną, odnosząc się do typowej dla strukturalizmu tendencji do myślenia w kategoriach binarnych opozycji. W przytoczonych fragmentach przewija się napięcie (skądinąd - termin także charakterystyczny dla Sławińskiego) ${ }^{58}$ między władzą interpretatora a władzą tekstu. $Z$ tej perspektywy analiza i interpretacja dzieła przypominają próbę sił (by pozostać w obrębie metaforyki militarnej), w której czytający stara się podporządkować sobie tekst (i na odwrót?). Najczęściej zmagania te kończą się stanem „równowagi dynamicznej”59, tymczasowego kompromisu, który jednak bardziej przypomina przeciąganie liny (czy to też przenośnia militarna?) niż trwałą ugodę (tu z pewnością wracamy do metaforyki wojennej).

Ujmując rzecz jeszcze szerzej, można powiedzieć, że działania opisane z zastosowaniem omówionych przenośni wiążą się ze strukturalistycznym logocentryzmem i umiłowaniem systemowości (powtórzmy jednak: bez wątpienia Sławiński doskonale zdaje sobie sprawę z utopijności, a nawet niebezpieczeństwa tych założeń), do których najwyraźniej nawiązuje pierwszy z cytatów (oczywiście we wspomnianym fragmencie praktyki te są ukazane tylko jako jedna $\mathrm{z}$ dwóch możliwości, ale posłużenie się wspomnianą, obrazową, przenośnią wyjaskrawia kontrast między dwoma podejściami do interpretacji).

Naturalnie celem tych uwag nie jest ukazanie Janusza Sławińskiego jako osoby o seksistowskich poglądach. Zależy mi jedynie na wyeksponowaniu, jak konkretny światopogląd literaturoznawczy określa światopogląd dyskursywny (czy też, by posłużyć się terminem Ryszarda Nycza: „tekstowy świat”) ${ }^{60}$, warunkujący stylistykę tekstów reprezentujących konkretny nurt ${ }^{61}$. Strukturalizm, oparty na

${ }^{57}$ Ibidem, s. 49.

58 Por. „stanem naturalnym poezji jest ciągłe napięcie” (J. Sławiński, Wokót teorii języka poetyckiego, [w:] Problemy teorii literatury. Seria 1, wybór H. Markiewicz, Wrocław 1967, s. 85, rozstrzelenie oryginalne). A także: „I przeciwnie: przechodzenie w przebiegu utworu od jednego sposobu mówienia do innego, zakłócenia regularności, napięcia pomiędzy różnymi sektorami stylistycznymi — intensyfikują obecność »ja« [...]" (J. Sławiński, O kategorii podmiotu lirycznego, [w:] idem, Dzieło - język - tradycja, Kraków 1998, s. 71).

${ }^{59}$ Parafrazuję: „Hierarchia funkcji [języka — dop. K.L.] przedstawia się jako układ o równowadze dynamicznej” (J. Sławiński, Wokót teorii języka poetyckiego..., s. 85).

${ }^{60}$ Nawiązuję do tytułu książki Nycza Tekstowy świat. Poststrukturalizm a wiedza o literaturze (Kraków 2000).

${ }^{61}$ Jednak aby dodatkowo oddać sprawiedliwość Sławińskiemu (i jego metaforom), należy wskazać na jeszcze jeden istotny szczegół. Badacz podkreśla bowiem, że „zamiar zawładnięcia” utworem w procesie interpretacji (J. Sławiński, Miejsce interpretacji, [w:] idem, Próby teoretycznoliterackie..., s. 69) dotyczy wielu, często bardzo odmiennych, szkół badawczych — nie tylko skupionych na filologicznej pracy nad tekstem, ale także zainspirowanych hermeneutyką, fenomenologią lub zaangażowanych społecznie (ibidem; J. Sławiński, Uwagi o interpretacji..., s. 45). Trudno z tą obserwacją się nie zgodzić. Jednocześnie to, że komentująca tę postawę metaforyka gwałtu pojawiła 
obiektywistycznych, logocentrycznych założeniach, w skrajnej postaci mógł zakładać konieczność podporządkowania sobie, opanowania literatury, co uprzywilejowało militarną metaforykę na jego gruncie. Z kolei brak wyczulenia na uważane za pozatekstowe czynniki pisania i lektury, takie jak płeć, czynił przenośnie odwołujące się do gwałtu pozornie neutralnymi ${ }^{62}$. Widzimy zarazem, że metafory z pola cielesności i erotyki, kiedy już pojawiają się w strukturalizmie, funkcjonują w zupełnie inny sposób niż w omówionych wcześniej nurtach ${ }^{63}$.

Paradoksalnie (?) obecność metaforyki cielesności i erotyki w dyskursie genderowym $^{64}$, a przynajmniej $\mathrm{w}$ jego wariantach wypracowanych $\mathrm{w}$ polskim literaturoznawstwie, na którym chciałabym się skoncentrować w tej części artykułu, jest dość niejednoznaczna. $\mathrm{Z}$ moich analiz wynika bowiem, że w obrębie tych ujęć nie wytworzyła się osobna grupa przenośni skupionych wokół interesujących

się w obrębie tekstu zakorzenionego w perspektywie strukturalistycznej, jest nie tylko świadectwem niekwestionowanej przenikliwości Sławińskiego, lecz także, jak sądzę, stylistycznym i światopoglądowym efektem współtworzonej przez autora strategii badawczej.

${ }^{62}$ Dla ścisłości trzeba jednak dodać, że motyw i metafora gwałtu odrywają dużą rolę również w krytyce feministycznej. Źródłem tych wyrażeń jest między innymi mit o Filomeli, Prokne i Tereusie, niekiedy także Szekspirowska Lawinia (Tytus Andronikus; por. J. Marcus, Still Practice, A/Wrested Alphabet: Toward a Feminist Aesthetic, [w:] Feminist Issues in Literary Scholarship, red. Sh. Benstock, Bloomington-Indianapolis 1987, s. 80-81), interpretowane jako opowieści o przemilczeniu i brutalnym wykluczeniu, które przez stulecia dotykały kobiecą twórczość (ibidem, s. 80-82). Warto dodać, że w interpretacji Jane Marcus przenośnie militarne i gwałtu pojawiają się między innymi również w opisie innych niż feministyczne, bardziej tradycyjnych (męskich? (post)strukturalistycznych?) sposobów lektury — autorka pisze bowiem o „rozpowszechnionej obecnie praktyce krytycznej zakładającej, że inicjalny akt krytyki jest agresywnym wtargnięciem własnego odczytania w tekst pisarza" (,the current practice of much literary criticism, where the initial act of critics is an aggressive forced entry into the text of the writer with a reading of one's own", ibidem, s. 80, przeł. K.L.). Co jednak ciekawe, autorka zaznacza, iż „rewolucyjna krytyka” (,revolutionary criticism"), w tym, jak można wnioskować, także przynajmniej niektóre warianty perspektywy feministycznej, nie zawsze jest pacyfistyczną metodą (ibidem). Tym samym Marcus umieszcza też opisywaną przez siebie strategię lektury w polu semantycznym wojny, choć już nie w obrębie metafor gwałtu.

${ }^{63} \mathrm{Na}$ marginesie warto zauważyć, że leksyka erotyczna przebija się do strukturalizmu i szkoły komunikacji literackiej z zewnątrz, z perspektywy czytelniczej. Nie bez powodu przecież Burzyńska $\mathrm{w}$ artykule omawiającym między innymi pierwsze nieśmiałe sygnały poststrukturalizmu w Polsce, odnosząc się do wcześniejszego, „naukowego” etapu literaturoznawstwa, pisała o swoich lekturach tekstów Sławińskiego i Głowińskiego, które odbywały się „z wypiekami na twarzy i bezsprzecznie erotyczną gęsią skórką" (A. Burzyńska, Anty-teoria literatury..., s. 156).

${ }^{64}$ Oczywiście, w poszczególnych nurtach, które opatruję tą nazwą, sytuacja ta nie wygląda jednolicie. Mówienie w tym kontekście o dyskursie genderowym jest zatem uproszczeniem, niezbędnym jednak w tak krótkim artykule. Szczegółowo specyfikę przenośni stosowanych we wskazanych nurtach w polskim literaturoznawstwie omówiłam we wspomnianej książce Metaforyczność $w$ dyskursie genderowym ...: w pracy tej znalazły się uwagi na temat (nie)obecności przenośni nawiązujących do cielesności i seksualności (s. 252-254) oraz przedstawionych dalej metafor śledztwa (s. 193-199), szafy (s. 226-251) i teatru (s. 144-166). 
mnie pól semantycznych ${ }^{65}$. Jednocześnie problematyka cielesności i erotyki towarzyszy innym typom przenośni. W tej części rozważań nie będzie zatem mowy o metakrytyczności w poprzednim rozumieniu; nie oznacza to jednak, że opisane dalej zjawiska nie prowokują pewnych teoretycznych refleksji — wspominam o nich dalej.

Zacznijmy od metafor, które można nazwać detektywistycznymi lub śledztwa. Opisują one etyczny wymiar pracy literaturoznawczej nastawionej poniekąd rewizjonistycznie, skoncentrowanej na odkrywaniu i rewaloryzowaniu wątków dotychczas marginalizowanych w narracji krytycznej i teoretycznoliterackiej. Wyrazistym, a zarazem nawiązującym przede wszystkim do problematyki cielesności ${ }^{66}$, przykładem są wyrażenia, jakimi w nawiązującym do perspektywy queerowej studium poświęconym Marii Komornickiej posłużyła się Izabela Morska (dawniej Filipiak):

${ }^{65}$ Dla ścisłości trzeba jednak dodać, że choć w polskim dyskursie genderowym tego rodzaju przenośnie nie tworzą tak wyrazistej grupy jak choćby w wypadku krytyki feministycznej i poststrukturalizmu, nie oznacza to, iż nie ma ich w omawianych nurtach wcale. Jako przykład warto podać następujący fragment pracy Piotra Sobolczyka: „Jeśli poprzednik jest moim rówieśnikiem i, tak jak w jednej (»wielostronnej«) wersji gejowskiego seksu, on może mnie pieprzyć najpierw, a potem ja jego (albo odwrotnie) i potem, oprócz tego [na szczycie tego] (albo na dole) każdy z nas bierze kogoś innego, wtedy jako rówieśnik on już nie jest »ideą«, a ja nie jestem »kopią«, ani, dosiadając go, nie czynię go kopią" (,If the predecessor is my peer, and, as in one (»versatile«) version of gay sex, he can fuck me first and then I fuck him (or the other way round), and then, on top of this (or on bottom of this), he goes with someone else and I go with someone else - then as a peer he is no longer the »idea«, then I am not a »copy«, nor do I, by mounting him, make him a copy", P. Sobolczyk Polish Queer Modernism, Frankfurt am Main 2015, s. 137, przeł. K.L.). Cytat ten, rozwijający rozważania Leo Bersaniego, przeformułowujące z kolei znany model przekształceń literatury zaproponowany przez Harolda Blooma, pochodzi z pracy reprezentującej perspektywę queerową; jakże inna jest jego metaforyczność od przytoczonych wcześniej przenośni typowych dla poststrukturalizmu czy krytyki feministycznej. Z pewnością teoretyczne zaplecze rozważań autora wpływa również na metafory zastosowane przez badacza i sposób ich wykorzystania.

Przy okazji warto dodać, że w interesującym mnie dyskursie można także znaleźć nawiązania do metaforyki gwałtu. W tym kontekście należy wspomnieć inny tekst Piotra Sobolczyka, w którym autor z perspektywy queerowej analizuje tego rodzaju zabiegi we współczesnej polskiej prozie (idem, Gwatt korporacyjny i gwalt korporealny — dwa spojrzenia na pewna metafore, [w:] Przyjemność i cierpienie = Genuss und Qual. Studia i szkice. 2, red. G. Jaśkiewicz, J. Wolski, Rzeszów 2014, s. 193-213). Chodzi tu oczywiście o zjawiska z innego poziomu, ponieważ wspomniane przenośnie badacz odkrywa w tekstach literackich, nie używając ich w funkcji metakrytycznej. Wpisuje je jednak w szerszy kontekst rozważań na temat (nie)normatywności określonych praktyk seksualnych (ibidem).

66 Trzeba zarazem zaznaczyć, że przywołana dalej metafora Morskiej ma tekstualną (poniekąd poststrukturalistyczną) genezę, ponieważ nawiązuje do dyskusji Jacques'a Derridy i Jacques'a Lacana dotyczącej opowiadania Edgara Allana Poego Skradziony list. Autorka odwołuje się do: J. Lacan, Seminar on „The Purloined Letter”, przeł. J. Mehlman, „Yale French Studies” 1972, nr 48, s. 38-72; J. Derrida, The Purveyor of Truth, przeł. W. Domingo et al., „,Yale French Studies" 1975, nr 52, s. 31-113 (por. I. Filipiak [zachowuję nazwisko podane na karcie tytułowej], Obszary odmienności. Rzecz o Marii Komornickiej, Gdańsk 2006, s. 497, przyp. 1, 2). 
Czy Księga poezji idyllicznej wraz z jej niejednorodnością jako założeniem nie jest przypadkiem autorskim odtworzeniem miejsca zbrodni? W takim razie — gdzie znajduje się ciało? (I jaką ma ono płeć?) ${ }^{67}$.

Podobne wątki przewijają się także w innych wyrażeniach, w których mowa na przykład o „pracy interpretatora-detektyw a” polegającej „na umiejętności deszyfrowania »ukrytych sygnałów lub aluzji, sekretów w tekście, symboliki«"68 i „tropieniu” w tekstach literackich nie tylko zabiegów formalnych, lecz także doświadczeń realnych osób, w czym można dostrzec upomnienie się również o ciała stojące za konkretnymi tekstami i wobec nich ${ }^{69}$.

Kolejnym wartym wspomnienia typem wyrażeń są różne warianty, popularnej zwłaszcza w krytyce gejowskiej, lesbijskiej i queerowej, metafory szafy/ toalety $^{70}$. W tego rodzaju zabiegach, w literaturoznawstwie opisujących literackie reprezentacje przemocy dotykającej osoby nieheteroseksualne, szczególnie wyraźnie dochodzi do głosu materialny, cielesny aspekt przenośni ${ }^{71}$. Konotowane przez przenośnię poczucie zamknięcia i osaczenia ma więc zyskiwać konkretny wymiar. Jako przykład podam fragmenty z tekstów Błażeja Warkockiego i Tomasza Kaliściaka (drugi cytat dotyczy utworu Józefa Czechowicza Opowieść o papierowej koronie):

Toaleta łączy przecież prywatne i publiczne, jawne i skrywane, brutalnie pospolite (miejski klozet) i ezoterycznie ulotne (makijaż). Toaleta uspójnia zapośredniczony w kulturze diapazon homoseksualnej wrażliwości [...]. Toaleta, jako miejsce na wskroś cielesne i seksualne, wykazuje niezwykłą odpowiedniość — bo przecież homoseksualista jest postrzegany przede wszystkim jako byt cielesny i seksualny. Toaleta staje się metaforą ${ }^{72}$.

${ }^{67}$ I. Filipiak, Obszary odmienności..., s. 75.

${ }^{68}$ R. Cieślak, Mężczyzna w teatrze ptci kulturowej. Poetycki paradygmat pożądania homoerotycznego. (Rzecz o wierszach Jacka Dehnela), [w:] Lektury ptci. Polskie (kon)teksty, red. M. Dąbrowski, Warszawa 2008, s. 358. Autor cytuje pracę Pawła Leszkowicza i Tomka Kitlińskiego (por. P. Leszkowicz, T. Kitliński, Miłość i demokracja. Rozważania o kwestii homoseksualnej w Polsce, Kraków 2005, s. 155), do której odnoszą się uwagi.

69 Por. uwagi Ingi Iwasiów dotyczące twórczości Allana Hollinghursta: „Homoseksualista opowiada nam swą historię, mając świadomość kontynuacji, tropi znajome figury, teksty, aluzje, jest kronikarzem schadzek w łaźniach rzymskich i londyńskich" (I. Iwasiów, Kobiecość w tekście homoerotycznym, [w:] Kobiety w literaturze. Materiaty z II Międzyuczelnianej Sesji Studentów i Naukowców z cyklu „Świat jeden, ale nie jednolity”, wstęp i red. L. Wiśniewska, Bydgoszcz 1999, s. 196).

${ }^{70}$ Słowo „toaleta” bywało używane we wczesnych polskich tłumaczeniach wyrażenia. Więcej na temat metafory szafy — oprócz wspomnianej książki mojego autorstwa — por. też K. Lisowska, Przenośnie w dyskursie genderowym polskiego literaturoznawstwa: moda czy coś więcej? Przykład metafory szafy w tekstach Błażeja Warkockiego, [w:] Tematy modne w humanistyce. Studia interdyscyplinarne, red. Ł. Grajewski et al., Torun 2015, s. 84-91.

${ }^{71}$ Por. też pracę M.P. Browna, w której autor podejmuje to zagadnienie Closet Space. Geographies of Metaphor from the Body to the Globe, London-New York 2000, tu s. 3.

${ }^{72}$ B. Warkocki, Różowy język. Literatura i polityka kultury na początku wieku, Warszawa 2013. 
„Szafę” Henryka należy więc rozumieć także jako symboliczną przestrzeń przemocy i przymusu. Król jest uwięziony w pałacu, znajduje się jednocześnie wewnątrz i na zewnątrz „szafy" uwikłany zarówno we własną homoseksualność, jak i w opresjonującą władzę ${ }^{73}$.

Po raz kolejny, szczególnie wyraźnie w pierwszym z przytoczonych fragmentów („Toaleta staje się metaforą”), widzimy zatem próbę wyjścia poza tekstualny wymiar przenośni i wskazania nie tylko jej cielesnego (zgodnie choćby z kognitywną teorią metafory), lecz także konkretnego, dotyczącego niemal jednostkowej egzystencji aspektu.

$\mathrm{Na}$ koniec trzeba wspomnieć o przenośniach z pola semantycznego teatru. Najkrócej rzecz ujmując, zabiegi te, mające wiele znaczeń i pełniące różne funkcje, dotyczą literackich i kulturowych reprezentacji problemu performatywności płci. Jak się zdaje, w tego rodzaju wyrażeniach cielesność funkcjonuje w dwojaki sposób: z jednej strony jako zakorzenione w poststrukturalistycznej retoryce tekstów Judith Butler zabiegi te wskazują na złudność jakichkolwiek wyobrażeń o istnieniu przeddyskursywnej (fizycznej) podmiotowości, z drugiej zaś, co zresztą wiąże się także z niejednoznacznością i wielopłaszczyznowością koncepcji wspomnianej filozofki ${ }^{74}$, są one niekiedy nastawione na uchwycenie doświadczeń realnych ciał ${ }^{75}$ zamkniętych w normach i konwencjach dotyczących płci. Wydaje się, że wspomnianą dwoistość ukazują następujące cytaty:

płciowość nie jest kwestią ustalonej wiedzy, tylko wiary, negocjacji, nawet inscenizacyjnego przymusu, w którym cielesność nie jest niczym „realnym”, lecz pozostaje wtórna wobec jakiegoś bardziej pierwotnego, choć nigdy nieskodyfikowanego wyobrażenia. Tym samym płciowość staje się elementem natrętnego, samoparodiującego się rytuału — pustych gestów wykonywanych w teatrze rozszczepionej egzystencji ${ }^{76}$.

Wydaje mi się, że wiele fenomenów w życiu Komornickiej ma związek z przebraniem i ja pozwalam swojej bohaterce się przebrać. I w tym przebraniu działać. Bostrój i to, co on może z nami uczynić, jest w kontekście Komornickiej niezwykle istotne ${ }^{77}$.

Jak widzimy, pierwszy fragment eksponuje dyskursywny wymiar cielesności, drugi zaś stara się — mimo wszystko — wskazać materialność i konkretność

73 T. Kaliściak, Katastrofy odmieńców, Katowice 2011, s. 63.

74 Jak, komentując koncepcję filozofki, zauważa Świerkosz: „Butler twierdzi bowiem, że nie ma dostępu do »czystej postaci« materialności ani poza, ani przed oznaczeniem, co jednak nie oznacza, że efekt lingwistyczny jest tożsamy z danym wycinkiem materii, który nazywa. Materialność nie jest redukowalna do semantycznych struktur języka" (eadem, Poza metafore ..., s. 187).

75 Por. choćby znamienny tytuł książki Butler Bodies That Matter. On the Discursive Limits of "Sex" (New York-London 1993).

76 D. Matuszek, - Kto ty jesteś? - Maty Hans. Rymkiewicza Freudem, „Teksty Drugie” 2015, nr 2, s. 221.

77 Akty radykalne. Rozmowa z Izabela Filipiak, [w:] K.E. Zdanowicz, Kto się boi Marii K.? Sztuka $i$ wykluczenie, Katowice 2004, s. 97-98. Powyższy, autotematyczny fragment dotyczący dramatu Ksiega Em (por. I. Filipiak, Księga Em, Warszawa 2005), przywołuję, ponieważ teksty literackie i naukowe - poświęcone przez Morską Komornickiej/Włastowi tworzą wspólnie jeden projekt, w którym to, co literaturoznawcze, jest nierozerwalnie złączone z tym, co artystyczne. 
doświadczeń przezierające spod figuratywności języka. Po raz kolejny zatem do głosu dochodzi wspomniane napięcie między tekstem a cielesnością.

Erotyka i, zwłaszcza, cielesność towarzyszą więc różnym typom metaforyczności w dyskursie genderowym w rodzimym literaturoznawstwie jako przede wszystkim zagadnienie badawcze, a nie stylistyczna inspiracja. Zarazem jednak właśnie dzięki tej właściwości interesujące mnie wątki szczególnie wyraźnie podkreślają źródłową, wyeksponowaną między innymi przez Świerkosz, sprzeczność metafor, które, chcąc reprezentować ciało, poddają je dalszej tekstualizacji. Należy oczywiście zadać również nasuwające się zapewne od razu pytanie, dlaczego w polskim literaturoznawczym dyskursie genderowym nie pojawił się na dużą skalę omawiany typ zabiegów. Za jeden z powodów można by uznać fakt, że problematyka ciała i seksualności jest przecież przedmiotem analiz uprawianych w ramach krytyki genderowej, gejowskiej, lesbijskiej, queerowej oraz studiów o męskości, a więc poddawanie tych aspektów metaforyzacji wydawałoby się zbędne $^{78}$. Jednak podobne wnioski dałoby się, jak sądzę, sformułować w odniesieniu do krytyki feministycznej, w której przecież, jak widzieliśmy, metafory cielesności i erotyki zajmują ważne miejsce. Można argumentować, że wspomniana perspektywa po prostu wyczerpała potencjał omawianych przenośni, ale takie stwierdzenie trudno udowodnić choćby ze względu na to, że relacje między dyskursem feministycznym a genderowym są złożone i nie dają się przedstawić jako proste - przyczynowo-skutkowe lub teleologiczne — zależności. Niewykluczone, iż przynajmniej za częściowe wytłumaczenie da się uznać szczególnie rozwinięte świadomość teoretyczną i krytyczną podejrzliwość, które w obrębie drugiego z wymienionych ujęć każą z rezerwą podchodzić do wszelkich generalizujących pojęć (a więc także do cielesności, seksualności i erotyki) i związanej z nimi metaforyczności. Nie jest to jednak z pewnością wyczerpująca odpowiedź i proponuję ją tylko jako jedną z możliwych i częściowych, zakładając, że dokładniejsze przedyskutowanie tej kwestii wymagałoby dalszych badań

Jak widzimy, metaforyka cielesności i erotyki przejawia się w dość niejednorodny i na swój sposób paradoksalny sposób w tekstach reprezentujących różne kierunki literaturoznawcze. Na czym polega owa paradoksalność? Po pierwsze, chodzi o nieusuwalny rozdźwięk między figuratywnością i tekstualnością wyrażeń a dążeniem autorek i autorów do uchwycenia tymi zabiegami materialnej realności opisywanych ciał. Dyskursywny wymiar przedstawionej metaforyczności częściowo wynika także $\mathrm{z}$ jej zakorzenienia $\mathrm{w}$ teorii, między innymi we wspomnianych rozważaniach francuskich filozofów. Wspomniana rozbieżność jest widoczna we wszystkich przenalizowanych nurtach oprócz strukturalizmu. Po drugie, omawiane zabiegi niejako podświadomie przenikają do programowo

78 Serdecznie dziękuję dr Weronice Lipszyc za wskazanie w trakcie dyskusji towarzyszącej referatowi będącemu podstawą niniejszego tekstu na możliwość takiego wythumaczenia (odczyt został wygłoszony w trakcie konferencji Poszerzanie poetyki 1: figury, chwyty, struktury tekstowe, Wydział Polonistyki, Uniwersytet Warszawski, 9.09.2019). 
niecielesnego strukturalizmu. Po trzecie - o czym wspomniałam na marginesie rozważań, a co trzeba tu podkreślić — w krytyce feministycznej pojawia się, również związana z problematyką cielesności, metaforyka militarna lub w jakiś sposób odsyłająca do problemu gwałtu, co czyni specyfikę krytycznofeministycznej metaforyczności bardziej skomplikowaną. Po czwarte, w dyskursie genderowym (a przynajmniej $\mathrm{w}$ jego wariancie wypracowanym $\mathrm{w}$ polskim literaturoznawstwie), mocno przecież związanym z poststrukturalizmem i ujęciem feministycznym, przenośnie związane $z$ cielesnością i erotyką odgrywają, jak się wydaje, drugorzędną rolę.

$\mathrm{Z}$ zamieszczonych uwag wynika też, że metafory niejednokrotnie pełnią funkcję metakrytyczną, czyli wskazują na perspektywę badawczą przyjętą w danej wypowiedzi literaturoznawczej. Co jednak ważne, zabiegi z podobnego pola semantycznego w odmiennych ujęciach problematyzują często zdecydowanie odrębne treści i przywołują zróżnicowane asocjacje. Uważna analiza metaforyczności ujawnia też pewne aporie typowe dla tego rodzaju zabiegów, szczególnie dobrze widoczne w kontekście wyrażeń z pola semantycznego cielesności i erotyki. Mówiąc nieco strukturalistycznym językiem, można zauważyć, że porządkujący (metakrytyczny) charakter przenośni stale ściera się z ich nieuniknioną (i nieprzewidywalną) wieloznacznością ${ }^{79}$, czyniąc metafory literaturoznawcze istotnym i stale inspirującym przedmiotem refleksji teoretycznej.

\section{Bibliografia}

Akty radykalne. Rozmowa z Izabela Filipiak, [w:] K.E. Zdanowicz, Kto się boi Marii K.? Sztuka i wykluczenie, Katowice 2004.

Araszkiewicz A., Zapomniana rewolucja. Rozkwit kobiecego pisania $w$ dwudziestoleciu międzywojennym, Warszawa 2014.

Balcerzan E., Literackość. Modele, gradacje, eksperymenty, Toruń 2013.

Balcerzan E., Słowo wstępne (i tu metafora wahadła), [w:] Porwani przez przenośnie. O literaturoznawczych metaforach, red. E. Balcerzan, A. Kwiatkowska, wstęp E. Balcerzan, Poznań 2007.

Barthes R., Fragmenty dyskursu miłosnego, przeł. M. Bieńczyk, Warszawa 1999.

Borkowska G., Metafora drożdzy. Co to jest literatura/poezja kobieca, [w:] Ciało i tekst. Feminizm w literaturoznawstwie - antologia szkiców, red. A. Nasiłowska, Warszawa 2001.

Brown M.P., Closet Space. Geographies of Metaphor from the Body to the Globe, London-New York 2000.

Burzyńska A., Anty-teoria literatury, Kraków 2006.

Burzyńska A., Feminizm, [w:] A. Burzyńska, M.P. Markowski, Teorie literatury XX wieku. Podręcznik, Kraków 2007.

Butler J., Bodies That Matter. On the Discursive Limits of "Sex", New York-London 1993.

${ }^{79}$ Choć zatem, jak zauważa Max Black, metafory bardziej skomplikowane niż te, które zdążyły się zakorzenić w języku, nie podlegają parafrazie, to „»Wyjaśnienie«” czy analiza ich „podstaw [...], jeśli nie traktowane jako adekwatny substytut poznawczy oryginału, mogą być wyjątkowo wartościowe” (M. Black, Metafora, przeł. J. Japola, „Pamiętnik Literacki” 1971, z. 3, s. 233). Niniejszy artykuł jest właśnie próbą dostarczenia tego rodzaju rozważań. 
Cieślak R., Mężczyzna w teatrze ptci kulturowej. Poetycki paradygmat pożądania homoerotycznego. (Rzecz o wierszach Jacka Dehnela), [w:] Lektury ptci. Polskie (kon)teksty, red. M. Dąbrowski, Warszawa 2008.

Derrida J., The Purveyor of Truth, przeł. W. Domingo, J. Hulbert, M.R. Logan, M. Ron, „Yale French Studies" 1975, nr 52.

Dobrzyńska T., Metafora, Wrocław 1984.

Dybel P., Zagadka „,drugiej płci”. Spory wokót różnicy seksualnej w psychoanalizie i w feminizmie, Kraków 2012.

Edelman L., Homographesis. Essays in Gay Literary and Cultural Theory, London-New York 1994. Eribon D., Michel Foucault et ses contemporaines, Paris 1994.

Filipiak I., Księga Em, Warszawa 2005.

Filipiak I., Obszary odmienności. Rzecz o Marii Komornickiej, Gdańsk 2006.

Grajewski W., Nauka lektury wedlug Rolanda Barthes'a, [w:] Problemy odbioru i odbiorcy. Studia, red. T. Bujnicki, J. Sławiński, Wrocław 1977.

Iwasiów I., Kobiecość w tekście homoerotycznym, [w:] Kobiety w literaturze. Materiały z II Międzyuczelnianej Sesji Studentów i Naukowców z cyklu ,,Świat jeden, ale nie jednolity”, wstęp i red. L. Wiśniewska, Bydgoszcz 1999.

Iwasiów I., Parafrazy i reinterpretacje. Wyktady z teorii i praktyki czytania, Szczecin 2004.

Iwasiów I., Rewindykacje. Kobieta czytająca dzisiaj, Kraków 2002.

Kaliściak T., Katastrofy odmieńców, Katowice 2011.

Karasińska M., Na scenie tekstu, [w:] Porwani przez przenośnie. O literaturoznawczych metaforach, red. E. Balcerzan, A. Kwiatkowska, wstęp E. Balcerzan, Poznań 2007.

Kłosińska K., Feministyczna krytyka literacka, Katowice 2010.

Korwin-Piotrowska D., Poetyka. Przewodnik po świecie tekstów, Kraków 2011.

Kozicka D., Krytyczne (nie)porządki. Studia o wspótczesnej krytyce literackiej w Polsce, Kraków 2012.

Kraskowska E., Dyskurs feministyczny w stowiańskiej literaturze, krytyce i teorii po roku 1989, [w:] Literatury stowiańskie po 1989 roku. Nowe zjawiska, tendencje, perspektywy, t. 2. Feminizm, red. E. Kraskowska, Warszawa 2005.

Kristeva J., Polylogue, Paris 1977.

Kuźma E., Metafory Janusza Stawińskiego, „Teksty Drugie” 1994, nr 4.

Lacan J., Seminar on “The Purloined Letter”, przeł. J. Mehlman, „Yale French Studies” 1972, nr 48.

Leszkowicz P., Kitliński T., Miłość i demokracja. Rozważania o kwestii homoseksualnej w Polsce, Kraków 2005.

Lisowska K., Metaforyczność w dyskursie genderowym polskiego literaturoznawstwa po 1989 roku, Kraków 2019.

Lisowska K., Przenośnie $w$ dyskursie genderowym polskiego literaturoznawstwa: moda czy coś więcej? Przyktad metafory szafy w tekstach Btazeja Warkockiego, [w:] Tematy modne w humanistyce. Studia interdyscyplinarne, red. Ł. Grajewski, J. Osiński, A. Szwagrzyk, P. Tański, Torun 2015.

Marcus J., Still Practice, A/Wrested Alphabet: Toward a Feminist Aesthetic, [w:] Feminist Issues in Literary Scholarship, red. Sh. Benstock, Bloomington-Indianapolis 1987.

Markowski M.P., Ciało, które czyta, ciało, które pisze, [w:] R. Barthes, S/Z, przeł. M.P. Markowski, M. Gołębiewska, Kraków 1999, s. 5-34.

Matuszek D., - Kto ty jesteś? — Mały Hans. Rymkiewicza Freudem, „Teksty Drugie” 2015, nr 2.

Nycz R., Tekstowy świat. Poststrukturalizm a wiedza o literaturze, Kraków 2000.

Rewers E., Język i przestrzeń w poststrukturalistycznej filozofii kultury, Poznań 1996.

Sławiński J., Analiza, interpretacja i wartościowanie dzieła literackiego, [w:] idem, Próby teoretycznoliterackie. Prace wybrane, Kraków 2000.

Sławiński J., Miejsce interpretacji, [w:] idem, Próby teoretycznoliterackie, Kraków 2000. 
Sławiński J., O kategorii podmiotu lirycznego, [w:] idem, Dzieło — język — tradycja, Kraków 1998.

Sławiński J., Wokót teorii języka poetyckiego, [w:] Problemy teorii literatury. Seria 1, wyb. H. Markiewicz, Wrocław 1967.

Sławiński J., Uwagi o interpretacji (literaturoznawczej), [w:] idem, Próby teoretycznoliterackie, Kraków 2000.

Sobolczyk P., Gwalt korporacyjny i gwalt korporealny — dwa spojrzenia na pewna metafore, [w:] Przyjemność i cierpienie = Genuss und Qual. Studia i szkice. 2, red. G. Jaśkiewicz, J. Wolski, Rzeszów 2014.

Sobolczyk P., Polish Queer Modernism, Frankfurt am Main 2015.

Świerkosz M., Arachne i Atena. Literatura, polityka i kobiecy klasycyzm, Kraków 2017.

Świerkosz M., Poza metaforę? Od feminizmu korporalnego do korporalnej teorii narracji, [w:] Anatomia dyskursu. Wiedza o literaturze z punktu widzenia obserwatora III, red. B. Balicki, B. Ryż, E. Szczerbuk, Wrocław 2008.

Warkocki B., Różowy język. Literatura i polityka kultury na początku wieku, Warszawa 2013.

Wysłouch S., Gramatyka i geometria — dwie miłości (literaturoznawców), [w:] Porwani przez przenośnie. O literaturoznawczych metaforach, red. E. Balcerzan, A. Kwiatkowska, wstęp E. Balcerzan, Poznań 2007.

\title{
How do metaphors express a literary studies worldview? An analysis of selected examples of theoretical and critical texts
}

\author{
Summary
}

In the article, Katarzyna Lisowska analyzes selected literary studies metaphors (Edward Balcerzan's term) in order to discuss the way in which they represent the academic worldview of the author. The paper focuses on the phrases from the semantic field of corporeality and/or eroticism and their presence in four influential methodologies: structuralism, post-structuralism (as well as the perspectives related to it: deconstruction and deconstructionism), feminist criticism and gender studies discourse. The analyses reveal a significant role of metaphors in expressing and formulating the assumptions of a given methodology, as well as some paradoxes which result from the application of the presented phrases.

Keywords: metaphor, metacritical function of metaphor, structuralism, post-structuralism, feminist literary criticism, gender studies discourse 